\title{
IT Consulting and Software Services by Outsourcing Makes a Company World Leader- A Case Study of Infosys Ltd.
}

\author{
M. Rajeshwari ${ }^{\mathbf{1} \& 2}$ \& Krishna Prasad $K^{\mathbf{3}}$ \\ ${ }^{1}$ Research Scholar, College of Computer Science and Information Science,
} Srinivas University, Mangalore, India.

${ }^{2}$ Assistant Professor, Department of Computer Science, St. Philomena College, Puttur, India

${ }^{3}$ College of Computer Science and Information Science, Srinivas University, Mangalore,India

Email: rajimuraleedhar@gmail.com

Type of the Paper: Explorative Research.

Type of Review: Peer Reviewed.

Indexed In: OpenAIRE.

DOI: http://doi.org/10.5281/zenodo.3510296.

Google Scholar Citation: IJCSBE

How to Cite this Paper:

Rajeshwari, M., \& Krishna Prasad, K. (2019). IT Consulting and Software Services by Outsourcing Makes a Company World Leader- A Case Study of Infosys Ltd. International Journal of Case Studies in Business, IT, and Education (IJCSBE), 3(2), 1-13.

DOI: http://doi.org/10.5281/zenodo.3510296.

International Journal of Case Studies in Business, IT and Education (IJCSBE)

A Refereed International Journal of Srinivas University, India.

IFSIJ Journal Impact Factor for 2019-20 $=4.252$

(C) With Authors.

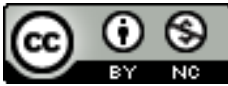

This work is licensed under a Creative Commons Attribution-Non Commercial 4.0 International License subject to proper citation to the publication source of the work.

Disclaimer: The scholarly papers as reviewed and published by the Srinivas Publications (S.P.), India are the views and opinions of their respective authors and are not the views or opinions of the S.P. The S.P. disclaims of any harm or loss caused due to the published content to any party. 


\title{
IT Consulting and Software Services by Outsourcing Makes a Company World Leader- A Case Study of Infosys Ltd.
}

\author{
M. Rajeshwari ${ }^{1}$ \& 2 \& Krishna Prasad $K^{3}$ \\ ${ }^{1}$ Research Scholar, College of Computer Science and Information Science, \\ Srinivas University, Mangalore, India. \\ ${ }^{2}$ Assistant Professor, Department of Computer Science, St. Philomena College, Puttur, India \\ ${ }^{3}$ College of Computer Science and Information Science, Srinivas University, Mangalore,India \\ Email: rajimuraleedhar@gmail.com
}

\begin{abstract}
Infosys Limited is an Indian multinational IT company, located its headquarters in Bengaluru, Karnataka, and established in the year 1981, which offers information technology, Business consulting and outsourcing services. It was founded by seven engineers with an investment of 250 dollars in India. In 2018-19, Infosys secured fifth rank Globally for IT services. Its brand value increased by $8 \%$ to $\$ 6.5$ billion. N. R. Narayanamurthy(CEO) was leading the company since its establishment till 2014, for 21 years. Its market cap amounted to 46.52 billion dollars on March 29, 2019.In 2019, it has 228,123 employees working at different roles and campus, all over the world. Infosys offers development of software, repairs, and autonomous support services to economics, insurance, production, and businesses. Infosys planned to reduce the amount of work done on site by their manpower travelling visas in the United States by shipping more work overseas. By this way, Infosys aims to protect and improve margin benefits. The charges for onsite projects are 3-4 times more than those delivered out of India. Infosys has nearly 25\% work performed onsite and remaining from India. Forrester research has used Forrester wave methodology to classify Infosys as a leader in easy offshore capacities. The study also reviewed that Infosys, using a low-cost GDM or offshore delivery model, is the biggest of the six in terms of income for application-related services. This case study focused on various goals - business vs. operational metrics, profit vs. saving cost, and decreased service needs vs. better customer service. This Case study also helps to explore the strategies and advantages of providing IT services in terms of economic development and client demand.
\end{abstract}

Keywords: Infosys Limited, Forrester Wave Methodology, software services, outsourcing, IT services.

\section{INTRODUCTION :}

Infosys is a well-known multinational consulting and Information Technology Services Company founded in the year 1981. The firm mentioned in NASDAQ was constructed by N.R. Narayana murthy and six engineers with an initial investment of US\$ 250 [1]. It provides good market strategy to receive a US\$ 4.8 billion organization with market takings of around 33 billion United States dollars. Infosys has spread its corporation worldwide by working in 28 countries, including America, the Middle East, Europe, Asia-Pacific, China and Africa. Infosys offers a variety of services to improve and expand their growth in a competitive environment. Infosys clubs on-site high-quality consulting on business with off-site perfect execution of technology. This will finally set the cost to the client site on business. Application services enable the development, maintenance and modernisation of apps. Those services focus on offering best-quality apps, with less or easy maintenance. Services provided by Infosys BPO combines technology with knowledge of domain to produce processes on outsourcing. Infosys provides services to a wide spectrum of industries, 
including business functions, including finance, human resource management, data technology and other outsourcing domains [2].This case study examines the problem of "performance measurement" with outsourcing with following goals: (1) to determine how Infosys benchmarks the inner performance of prospective providers ; (2) to determine how the service organization assesses the expenses of the outsourcing decision ; (3) to develop efficient performance policies to assess the outsourcing decision [2].

This case study has 19 sections. Section 1 gives a brief introduction of the company and offered services. Section 2 gives the vision and mission of the company. Section 3 explores the background of the case study. It also tells about the objective of the case study. Section 4 gives the milestones of the company. Section 5 describes the strategies used to introduce, develop and to market the products and its services. Section 6 introduces varieties of services at different areas offered by Infosys. Section 7 lists important products and platforms of the company with their domain and verticals. Infosys subsidiaries are tabulated in section 8 . It also lists details of subsidiaries with services offered by them. Section 9 tabulates Infosys annual revenue history and growth rate, for the financial year from 2015 to 2019. Also graph of income and profit of Infosys is shown. Section 10 explains the major rivals of Infosys. This section has shown the competitions with major 10 companies and their positions. Section 11 discusses on the companies acquired by Infosys, its cost, and services offered by them. In section 12, major clients of the company are introduced. Green initiatives taken by the company and measures taken are explored in section 13. Stakeholders are discussed in the next section no.14. Corporate structure of Infosys is in the form of organization chart is displayed in the section 15. Next strength, weakness, opportunities and challenges faced by the Company are explained in the section 16. Finally, conclusion and further enhancement of the case study are written in sections 17 and 18 respectively.

\section{VISION AND MISSION :}

Infosys aims to provide best business solution by having efficient, best-in-class employees to become a standard corporation[3].Infosys maintains their clients, employees and society with true care, sincerity and consideration to achieve their goals [3].

\section{BACKGROUND :}

Infosys focuses on customer-oriented business models to create new opportunities with digital advances for businesses [4]. This new digital architecture drives results across five fields - Expertise, Insight, Innovation, Acceleration, and Assurance. New solutions and services in business are helping to speed up innovation, boost productivity, reduce costs and optimize the use of assets[5].The aim of this case study is to know the decision-making process used by Infosys Ltd companies to outsource their IT operations [6]. Outsourcing means providing an external provider with the business activity. A long-term, periodic relationship, where the supplier is liable for the full outcomes of outsourcing activities is called outsourcing. We see companies that have used outsourcing for their development, cost reduction, risk diversification or quality improvement[7-10]. There are only a few effective instances of off shoring, which has brought cost savings, innovation, quality improvement or other advantages, and these are mostly among big, globally engaged companies[11].Outsourcing should be seen as an instrument that enables the company tofocus on its $\mathrm{k}$ ey business.Based on the current growth in outsourcing (and also off shoring), backed by globalization, deregulation, the development of IT and communication techniques, advance deducation with specialization, we look forward to outsourcing to grow more height.[7-13].

\section{SUCCESS SAGA :}

The following table 1 lists the milestones of Infosys since 1981 to 2019.

Table1: Success saga of Infosys[14]

\begin{tabular}{|l|l|}
\hline Year & Milestone \\
\hline 1981 & Year of establishment \\
\hline 1992 & Transformed into a Public Limited Company in India \\
\hline 1993 & Received certification of ISO9001/TickIT \\
\hline
\end{tabular}




\begin{tabular}{|c|c|}
\hline 1997 & Achieved SEI-CMM Level 4 \\
\hline 1999 & $\begin{array}{l}\text { - } \text { Mentioned in stock market NASDAQ } \\
\text { - } \text { Reached Annual revenues of \$100 Million } \\
\text { - Achieved SEI-CMM Level5 }\end{array}$ \\
\hline 2001 & Reached revenues of 400 million dollars. \\
\hline 2002 & Revenues succeeded to cross500million \\
\hline 2004 & Succeeded to cross $\$$ billion in revenues \\
\hline 2006 & Succeeded to cross $\$ 2$ billion in revenues \\
\hline 2007 & $\begin{array}{l}\text { - Reached } 3 \text { billion US dollars revenue. Employees count was more than } \\
70,000 \\
\text { - } \quad \text { Reported revenue of over 1billion dollars in the second quarter. }\end{array}$ \\
\hline 2008 & $\begin{array}{l}\text { - Succeeded to receive } 4.18 \text { billion dollars revenue. } \\
\text { - } \quad \text { More than } 1 \text { billion dollars was the Annual net profit. }\end{array}$ \\
\hline 2009 & $\begin{array}{l}\text { - The Global Dow considered company as a member. } \\
\text { - Employee power reached more than 1,00,000. }\end{array}$ \\
\hline 2010 & Obtained 5 billion dollars revenue \\
\hline 2011 & Obtained 6 billion dollars revenue, and employee count reached 1,25,000. \\
\hline 2012 & Made an entry on the NYSE market. \\
\hline 2016 & Reached revenues of US\$10 billion. \\
\hline 2018 & Successfully maintained 25 years on Indian Stock exchanges listing. \\
\hline 2019 & Infosys BPM was honoured with Best CSR Practice Award \\
\hline
\end{tabular}

\section{STRATEGIES :}

Infosys implements the three-in- a-box strategy that allocates the energy, time and resources of the organization in a balanced manner. Box 1 represents the current business to continue to run, box2 represents the past-to forget the reasons for successful growth, and box 3 represents the future-to create the new innovative model. Rich businesses implement this structure to address all practical dilemmas of how to balance an organization's critical state with conflicting innovation requirements [15-16].Infosys' aims at the skill development of employees more and more [17-18]. Infosys strongly trusts that the major factor that helps them achieve development is their client-focused approach. Their strategy focuses on a limited number of reputable big organisations paying attention to product quality rather than concentrating on countless tiny organisations without concern for quality. Their strategy focuses on creating a picture rather than cost-differentiating model for quality driven model. It offers value-added alternatives to its new customers by providing deep industry knowledge. The company concentrates on emerging technologies and innovations. In recent years, they have added new services, like infrastructure management and, system integration which have increased the success of the company.

Infosys focuses on gaining the price benefit of their global delivery model [3]. Infosys has its vision on Modular Global Sourcing i.e., an evolutionary outsourcing approach, which enables an enterprise to implement best-of-breed sourcing approaches by structuring business processes and IT systems into individual modules. The main principles for Modular Global Sourcing include, taking an enterprise-wide perspective of aligning the sourcing objectives with the business strategy. The new idea of global outsourcing strategy will focus on what and when to consider outsourcing and also knows the managing skills to deliver the services globally throughout the value chain.

With agile digital technology, business is empowered. Learning here remains to drive ongoing development by creating creative solutions ' digital abilities, knowledge and thoughts [19]. APIs for every business strategy used Ambient Intelligence and Intention Economy to build a collection of frameworks and business APIs. For example, mobile user APIs, APIs to provide basic price, product and order status data, digital payment wallet APIs, etc [20]. Infosys provides support across all sourcing and procurement management needs-from strategy formulation to BPM services and technology-providing comprehensive services. I.e. Infosys specialists outline the difficulties faced by procurement analytics and the holistic strategy required to resolve them. Fortunately, the combination 
of state-of - the-art visualization and artificial intelligence technology, coupled with models of' as a service', can finally provide the insights needed for real business value. Procurement solutions are designed to provide access to sophisticated AI-based skills, allowing quicker decision-making [2].

\section{INFOSYS SERVICES :}

Industries: Business solutions and service from Infosys assistance speed creativity, productivity, cost reduction and efficient use of assets. Some services are provided, such as Aerospace and Defence, Automotive, Banking and Capital Market, Education, Healthcare, Energy, Insurance, Logistics, Publishing, Utilities etc [21].

IT Services: With specialists, Infosys provides customers with a range of IT services [21].

Engineering Services: The services cover the entire engineering value chain spanning the sector's various verticals. Product engineering, lifecycle management, plant solutions and production processes. In the field of cloud apps and facilities, cyber safety, sophisticated analysis and information science, IOT services and the development of new digital experiences with end-users the company launched innovative services.

Consulting Services: The consulting services make further competitive and more capable of managing worldwide business core process excellence, IT strategies, learning \& complex change, next-generation trade, product innovation etc [21-22].

BPO Services: To offer outsourcing of process, Infosys BPO combines domain knowledge, process abilities and technology. All the business processes are offered with outsourcing [21-22].

\section{PRODUCTS AND PLATFORMS :}

Table 2: Important product and platform provided by company[21][23].

\begin{tabular}{|l|l|l|}
\hline $\begin{array}{l}\text { Products } \\
\text { Platform }\end{array}$ & Domain & Verticals \\
\hline EdgeVerveSystemss & $\begin{array}{l}\text { RPA platform/ Automation } \\
\text { tools }\end{array}$ & $\begin{array}{l}\text { BFSI (Banking and Financial Services), } \\
\text { Retail \& CPG (Consumer Packaged } \\
\text { Goods), Life-science, Manufacturing, } \\
\text { communications }\end{array}$ \\
\hline Finaclee & Core banking solutions & BFSI ((Banking and Financial Services) \\
\hline InfosysaNIA & Automation \&\&AL Platform & All \\
\hline Panayaa & $\begin{array}{l}\text { Test management \&\&Test } \\
\text { automation solution }\end{array}$ & All \\
\hline Skavaa & Digitals Commerce Platform & Retails \\
\hline Wingspan & Corporate Learning Solutions & All \\
\hline Flypp & Mobile Application Platform & Business and customer service \\
\hline $\begin{array}{l}\text { Infosys mConnect } \\
\text { enterprise middleware }\end{array}$ & $\begin{array}{l}\text { Mobile Services for websites and } \\
\text { ecommerce Platforms. }\end{array}$ \\
\hline $\begin{array}{l}\text { Infosys iPrower } \\
\text { Accessibility Assessment \& } \\
\text { Remediation }\end{array}$ & $\begin{array}{l}\text { Web accessibility by disabled (physically } \\
\text { challenged) users }\end{array}$ \\
\hline $\begin{array}{l}\text { Infosys iEngage } \\
\text { Employee Engagement }\end{array}$ & $\begin{array}{l}\text { Customer service on social networks(online } \\
\text { services) }\end{array}$ \\
\hline iTransform & Product Suite & Business and healthcare organizations \\
\hline $\begin{array}{l}\text { Infosys Unified } \\
\text { Communications } \\
\text { and Collaboration } \\
\text { (UC) }\end{array}$ & Retail industry solution & Retail Industry Communications \\
\hline
\end{tabular}




\section{INFOSYS SUBSIDIARIES :}

(1) EdgeVerve Systems Limited: EdgeVerve Systems, Infosys' fully-owned subsidiary, creates and provides new software goods on-site or as cloud-hosted business platforms. Its headquarters are situated in Bengaluru, Electronic City. EdgeVerve is looking forward to announcing the 18.0 AssistEdge RPA. It offers services like banking, interactive business, distributive trade, credit service, enterprise purchasing service. It provides a universal solution used for banking, Finacle. 547 million clients of financial organization across 84 countries are choosing it [24].

(2) Infosys BPM Limited: It is an outsourcing business process subsidiary. Infosys BPM provide its customers with transformative advantages through cost reduction, continuing productivity improvements, and process reengineering. It offers services on Human Resource, Finance \& Accounting, Sales and Fulfilment, Sourcing and Procurement, BPM Analytics, and Robotic Process Automation using outsourcing [9]. As of June 2019, Infosys BPM operates in Indiaand 16 countries with 32 delivery centers across 5 continents [24]. It provides job for 38,886 people from more than 100 nations.

(3) Infosys Consulting services: It was established in 2004. Infosys Consulting is a worldwide consultant to lead businesses in strategizing, process engineering and managing transformation programs that are enabled by technology. By combining creative and human-focused strategies with the new hi-tech developments, allow organisations to rethink their future and generate viable and sustainable company value for automotive, insurance, life sciences, energy, resources, and financial services, etc. Globally, it offers its services to more than 200 active customers.

(4) Infosys Public Services Inc: U.S. based Infosys subsidiary, offers service in business consulting and technology solutions. Infosys partner with public sector organisations in the US and Canada. In Rockville, Maryland, it has opened its new headquarters and delivery centre. Digitizing customer experience and ensuring optimal service delivery by adopting innovative technologies through rapid innovation. It provides services to the public such as consulting services, technology services, company mobility, cloud and infrastructure, cyber and safety, legacy modernization, procurement modernization analytics and insights, digital ERP services [24].

(5) Panaya: It was established in 2006. It is software as a service company (SaaS). It is present across Americas, the EMEA and Asia. Infosys fully acquired the Panaya group of companies in 2015. (6) Skava: Skava is one of the major providers of mobile and multi-touch point solutions to many of the top retailers in the US. The Skava platform transforms its e-commerce platform to mobile web, tablet, Facebook and in-store technologies. Skava has been a pioneer in app growth since 2002. The first retail location is fully optimized for tablets (t.staples.com) and works with various retailers to develop their in-store technology solutions.

(7) Noah Consulting LLC, a top subsidiary : It provides consulting services with management of information. This firm assists upstream oil and gas businesses to provide worldwide technology and outsourcing services to oil and gas customers [24].

\section{FINANCIAL GROWTH :}

Infosys annual revenue history and growth rate, for the financial year from 2006 to 2019 is shown below [21][25-26].The graph shown in Fig. 1 depicts that company has consistent profit margins [25]. The overall performance, i.e. income and profit of Infosys are also rising, as shown in Fig $1[25]$.

Table 3: Annual revenue of Infosys from financial year 2006 to 2019.

\begin{tabular}{|c|c|c|c|c|c|}
\hline Year & $\begin{array}{c}\text { Annual Revenue } \\
\text { (Millions of US } \\
\$ \$ \text { ) }\end{array}$ & $\begin{array}{c}\text { Annual Net } \\
\text { Income } \\
\text { (Millions of USs } \\
\text { \$) }\end{array}$ & $\begin{array}{c}\text { Annual Gross } \\
\text { Profit } \\
\text { (Millions of US \$) }\end{array}$ & $\begin{array}{c}\text { Annual } \\
\text { worldwide } \\
\text { Employee Count }\end{array}$ & $\begin{array}{c}\text { Annual } \\
\text { Growth } \\
\text { Rate (\%) }\end{array}$ \\
\hline 2019 & 11,799 & 2,200 & 4,112 & $2,28,123$ & 11.77 \\
\hline 2018 & 10,939 & 2,486 & 3,938 & $2,04,107$ & 1.87 \\
\hline 2017 & 10,208 & 2,140 & 3,762 & $2,00,364$ & 3.26 \\
\hline
\end{tabular}


International Journal of Case Studies in Business, IT, and Education

\begin{tabular}{|c|c|c|c|c|c|}
\hline 2016 & 9,501 & 2,052 & 3,551 & $1,94,044$ & 10.14 \\
\hline 2015 & 8,711 & 2,013 & 3,337 & $1,76,187$ & 9.84 \\
\hline 2014 & 8,249 & 1,751 & 2,957 & $1,60,405$ & 2.82 \\
\hline 2013 & 7,398 & 1,725 & 2,761 & $1,56,000$ & 4.00 \\
\hline 2012 & 6,994 & 1,716 & 2,876 & $1,50,000$ & 14.68 \\
\hline 2011 & 6,041 & 1,499 & 2,544 & $1,30,800$ & 14.94 \\
\hline 2010 & 4,804 & 1,313 & 2,055 & $1,13,800$ & 8.48 \\
\hline 2009 & 4,663 & 1,281 & 1,964 & $1,04,900$ & 15.02 \\
\hline 2008 & 4,176 & 1,163 & 1,723 & 91,200 & 26.32 \\
\hline 2007 & 3,090 & 850 & 1,313 & 72,200 & 37.00 \\
\hline 2006 & 2,152 & 555 & 908 & 52,700 & 43.21 \\
\hline
\end{tabular}

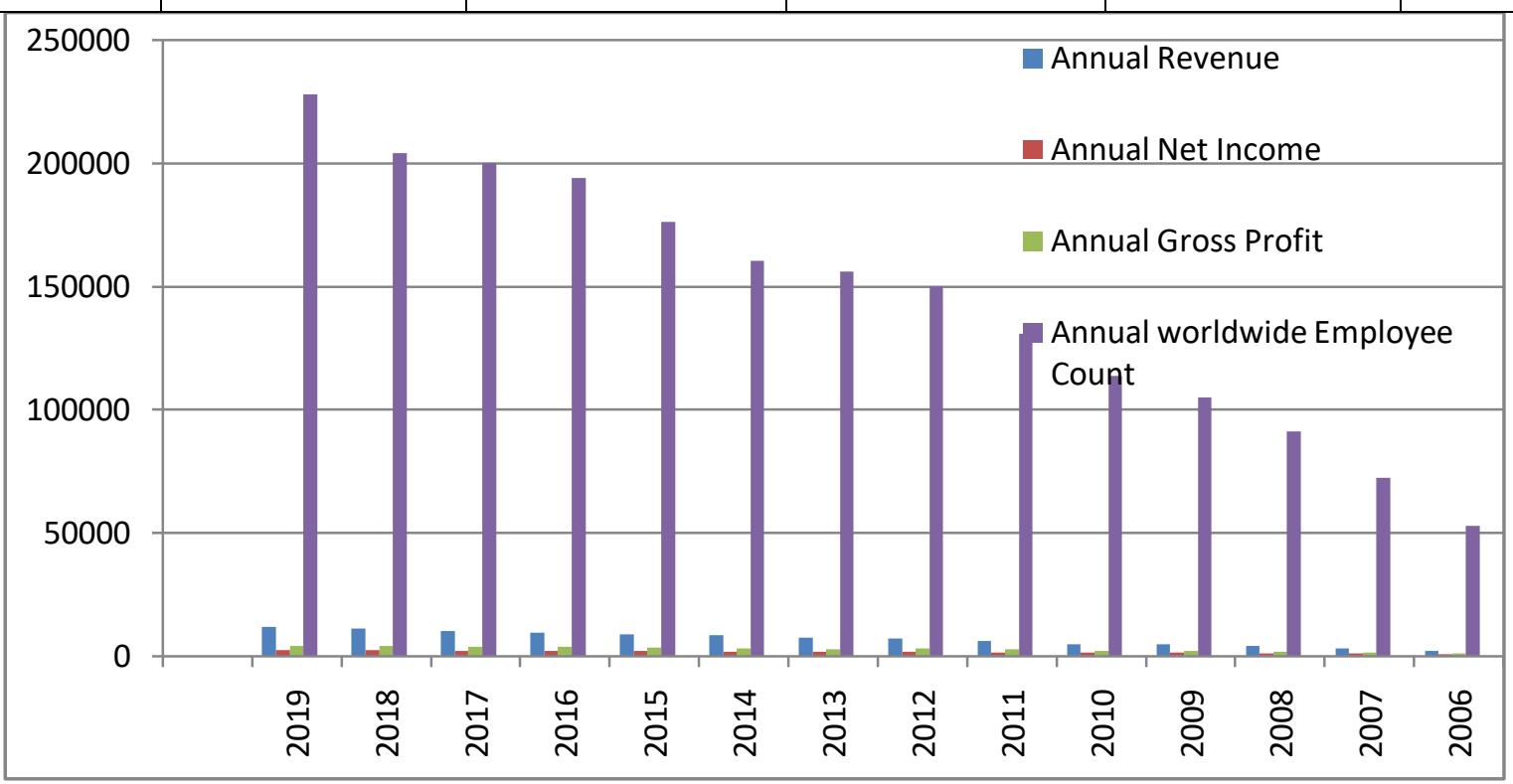

Fig. 1: Chart -Revenue, Net Income, Gross Profit, Employee count, Growth Rate

10. COMPETITORS :

Infosys' major competitors are Accenture, Wipro and TCS. As of July 2019, Infosys had $841.6 \mathrm{~K}$ followers on Facebook and $235.5 \mathrm{~K}$ followers on Twitter. Infosys has revenues of $\$ 11.8 \mathrm{~B}$ and 228,000 staff [27]. Accenture, Wipro, CTS, TCS, IBM, Deloitte, Capgemini, Tech Mahindra, HP and HCL are the top 10 competitors in Infosys' competitive set. Together, more than 48.7 million of their approximately 2.4 million staff have increased. Infosys has 228,000 employees and ranks 6th among its top 10 competitors. The top 10 rivals are on average 235,653[21][27]. 
Table 4: Top10 competitor lists of Infosys

\begin{tabular}{|c|c|c|c|c|}
\hline Ranking & IT Company & Workforce & Funding & Revenue \\
\hline & Infosys & 228,000 & $\$ 0$ & $\$ 11.8 \mathrm{~B}$ \\
\hline 1 & Accenture & 459,000 & $\cdots$ & $\$ 43.3 \mathrm{~B}$ \\
\hline 2 & Wipro & 150,000 & -- & $\$ 8.5 \mathrm{~B}$ \\
\hline 3 & Cognizant & 281,600 & $\$ 29.2 \mathrm{M}$ & $\$ 16.5 B$ \\
\hline 4. & TCS & 378,497 & -- & $\$ 908.8 \mathrm{M}$ \\
\hline 5 & IBM & 350,600 & -- & $\$ 77.9 \mathrm{~B}$ \\
\hline 6 & Deloitte & 286,200 & $\$ 19.5 \mathrm{M}$ & $\$ 43.2 \mathrm{~B}$ \\
\hline 7 & Capgemini & 204,904 & -- & $\$ 15.1 \mathrm{~B}$ \\
\hline 8 & Tech Mahindra & 78,304 & -- & $\$ 5.1 \mathrm{~B}$ \\
\hline 9 & $\mathrm{Hp}$ & 55,000 & $\$ 538$ & $\$ 58.7 \mathrm{~B}$ \\
\hline 10 & HCL & 120,081 & -- & $\$ 8.1 \mathrm{~B}$ \\
\hline
\end{tabular}

Infosys' revenue is ranked 7th among its top 10 rivals. The top 10 rivals are on average 26.3B. Infosys' income increased by 10.4 percent over the last three quarters. Specifically, income was $\$ 3.2 \mathrm{~B}$ in first quarter 2019; income was \$3.2B in fourth quarter2018; income was \$2.9B in third quarter 2018 [27].

\section{MAJOR ACQUISITIONS :}

Table5: Acquisitions of Infosys [28]

\begin{tabular}{|l|l|l|l|l|}
\hline Company & Located & Price (Million) & $\begin{array}{l}\text { Date } \\
(\mathbf{M M} / \text { YYYY) }\end{array}$ & Services \\
\hline $\begin{array}{l}\text { Expert } \\
\text { Information } \\
\text { Services }\end{array}$ & Australia & 23 & $12 / 2003$ & IT service \\
\hline $\begin{array}{l}\text { McCamish } \\
\text { Systems }\end{array}$ & USA & $\$ 38$ & $12 / 2009$ & Insurance and financial \\
\hline $\begin{array}{l}\text { Portland } \\
\text { Group }\end{array}$ & Australia & AUD 37 & $01 / 2012$ & $\begin{array}{l}\text { Strategic sourcing and } \\
\text { category management }\end{array}$ \\
\hline $\begin{array}{l}\text { Lodestone } \\
\text { Holding AG }\end{array}$ & Switzerland & US\$345 & $09 / 2012$ & Consultancy in Management \\
\hline Panaya & Israel & US\$200 & $03 / 2015$ & Technology of Automation \\
\hline Skava & USA & US\$120 & $04 / 2015$ & Digital experience solutions \\
\hline $\begin{array}{l}\text { Noah- } \\
\text { Consulting }\end{array}$ & USA & US\$70 & $11 / 2015$ & $\begin{array}{l}\text { Information management } \\
\text { consulting }\end{array}$ \\
\hline Skytree & USA & $\begin{array}{l}\text { Undisclosed } \\
\text { amount }\end{array}$ & $04 / 2017$ & Learning of machine \\
\hline Brilliant Basics & UK & GBP 7.5 & $08 / 2017$ & Design of Product \\
\hline Fluido & Finland & EUR 65 & $10 / 2018$ & $\begin{array}{l}\text { Advisor in Sales force and } \\
\text { partnership in consulting }\end{array}$ \\
\hline WongDoody & USA & US\$75 & $01 / 2019$ & Advertising and creative \\
\hline Stater & Netherlands & EUR 127.5 & $04 / 2019$ & Mortgage \\
\hline
\end{tabular}




\section{IMPORTANT CLIENTS :}

Infosys provides next-generation digital services and consulting and became a leader worldwide. In 45 countries it has around 1,336 happy consumers to pilot their digital change [29].

\section{GREEN INITIATIVES :}

Environmental conservation is responsible for creating a better world both for today and for the future. Infosys has more concern on its contractors, advisors and staff with a secure and healthy environment. Infosys considers each means of decreasing carbon trace, water usage and power use. Infosys has taken initiatives on Green Infrastructure, Energy Conservation, Water Sustainability, Biodiversity Conservation and Promotion, Waste Management and Green Innovation. Because of its commitment to use renewable energy, in May 2015, Infosys was qualified to join the RE100 renewable energy campaign [30].

\section{STAKEHOLDERS AND CORPORATE SOCIAL RESPONSIBILITY INITIATIVES :}

Clients, employees, investors, vendors or partners, government and local communities are the stakeholders of Infosys. Sustainable development of the communities in which it operates is an important part of its CSR [24]. It focuses on education, health care, arts and culture, rural development. Infosys Limited, a digital service and consulting conglomerate, has spent Rs. 342 crore against its prescribed CSR spending of Rs. 340 crore (2 percent of net profit of Rs. 17,018 Cr) on multiple CSR schemes as provided for in Section 135 of the Act [30].

\section{CORPORATE STRUCTURE :}

Since its establishment in 1981 till 2019, Infosys has 104 executives and 14 subsidiaries and its main 34 executives are shown in the given organizational chart[31].

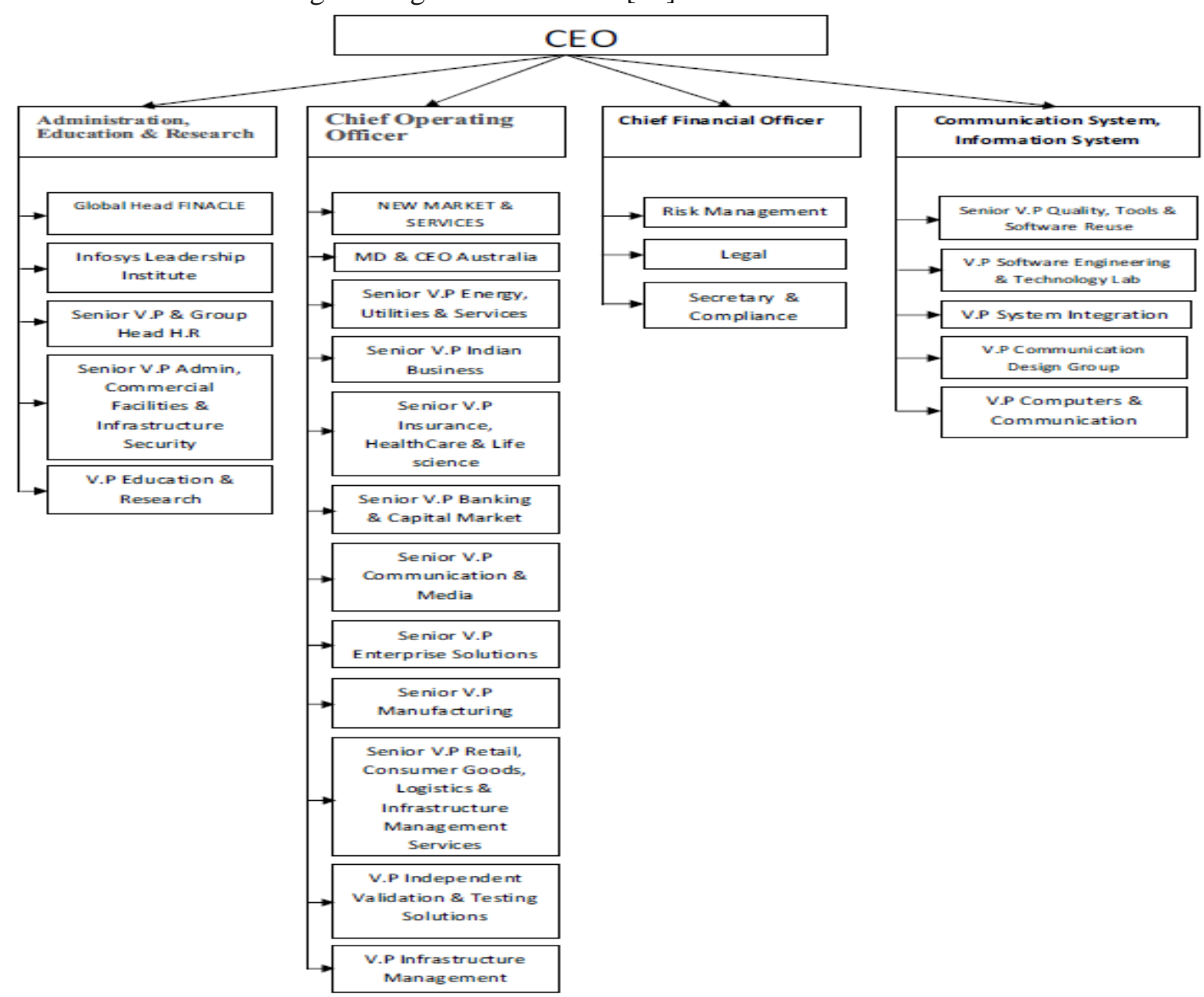

Fig 2: Infosys Organizational Structure 


\section{SWOC ANALYSIS :}

SWOC matrix / Analysis primary objective is to define the policies that a business can implement by using possibilities and considering challenges for its growth. SWOC analysis is commonly used as a mechanism for strategic planning [32].

Strengths of Infosys Limited: The Company has much strength that allows it to flourish in the marketplace. Some of the strengths of Infosys Limited are -

- Development of new technologies successful track record - product innovation.

- Strong Brand name- this brand name is useful to expand its new categories of product.

- Strong community of dealers- Here dealers and distributors of the company promote its products with training to the sales team to give details of the products.

- Automation of product quality operations by examining fluctuating market requirements.

- Company with expertise is finding the way to enter the new market and finding success.

- Over the years, a reliable distribution network enables a business to achieve most of its prospective market.

- Company has satisfied on its investment on new projects by getting profit in turn.

Weakness of Infosys Limited: Weaknesses are places where company can enhance.

- Still requires more strategies on marketing its product with its competitors.

- High attrition rate in work force - Compared with other industry organizations, Infosys Limited has a higher attrition rate. Therefore, it must spend much more on training and employee development.

- Compared with competitors, the inventory of days is high.

\subsubsection{Opportunities for Infosys Limited:}

- New environmental policies - The new designs will help to build the company to gain market share in the new product category by driving its technology.

- The company can boost its clients by offering a new market strategy for new technology services.

- New product categories are taken from the company's diversity and new income streams. This discovers new trends in consumer behaviour in the company's industry.

- The new taxation policy increases the company business and it creates new opportunity towards the profit.

Challenges Facing - External Strategic Factors:

- The steady growth of profit in markets depends on skilled workforce in global market

- Consumers use the online channel, the purchasing method they have altered from the physical infrastructure the way the supply chain model defines.

- Severe competition on products given by several industries downwards profitability and overall sales.

- Local distributors override the company strength by providing needs in the market at higher margins.

- Various strategies are regarded on the world market with regard to country-to-country changes in liability law.

- Profit of a company is inversely proportion to the cost of raw material.

Table 6: Infosys SWOC analysis [33]

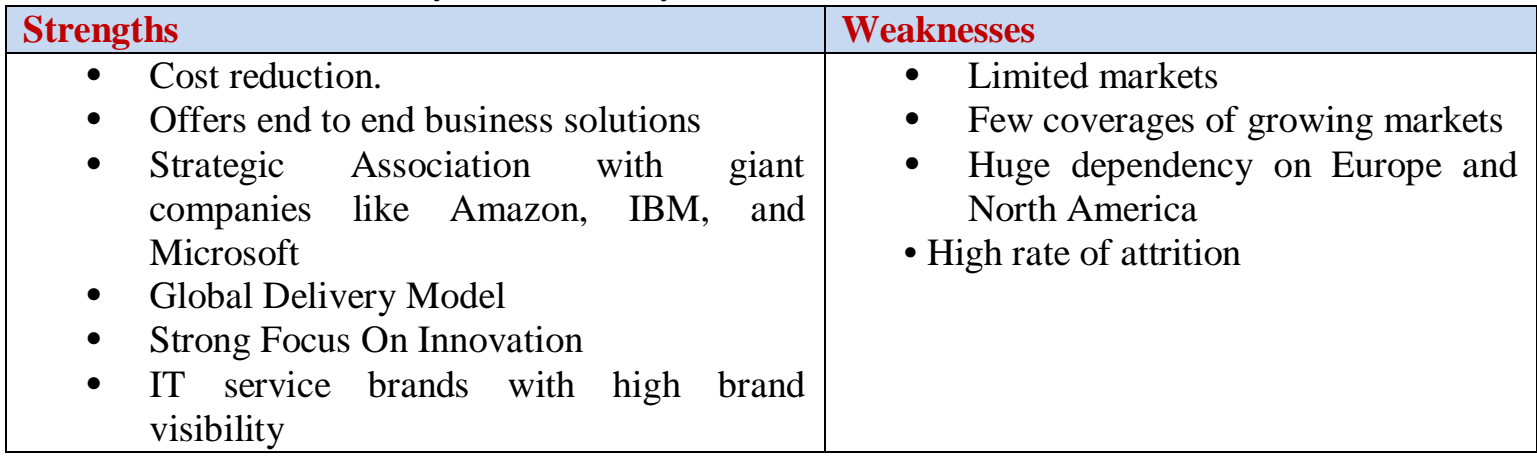




\begin{tabular}{|l|l|l|}
\hline Opportunities & Challenges \\
\hline$\bullet$ Invest in young technology businesses & $\bullet$ & Strongrivalry \\
- Expansion in spending on digital & & $\bullet$ Changes in US migration laws \\
technology & & Employee retention. \\
- New Technologies & Aims on sustainable growth \\
Increased need for cloud based & & \\
approaches & & \\
- Focus on promising markets & & \\
\hline
\end{tabular}

\section{CONCLUSION :}

This case study explores that Infosys work on its strategies with new ideas of information technology to reach each and every customer on their own way. With their strategic planning and leadership, Infosys has worked hard and even managed to remain competitive even in the era of a worldwide financial downturn. They still need to concentrate on inner and external variables that help to win the weakness and challenges [31][34]. It is very evident that Infosys services will play a significant part in their overall income. That is to say, $31.6 \%$ of its total income by economic services, $15.9 \%$ - retail, $13.5 \%$ - communications, $12.7 \%$ - energy, utilities, infrastructure and services, $10 \%$ - manufacturing, $7.7 \%$ - hi-tech and 6\% - life sciences[35]. By outsourcing its services worldwide, i.e. 2.3 percent from India, 24 percent from Europe, 61.2 percent from North America and 12.5 percent from the rest of the globe, Infosys obtained its total revenue.Also Infosys increased their employees count from 2,04,107 (March 2018) to 2,28,123(in March 2019) [35]. Outsourcing may be used to improve cost, quality, and service and time-to-market effectiveness.

Infosys has distributed its branches and centers of growth throughout India, Australia, Canada, Japan, UK and many other nations. Infosys set a fresh revenue record in 2017 by gaining second place among Indian IT businesses and the world's 596th biggest public company.

\section{FUTURE PLANS :}

Infosys focuses on innovative digital techniques to make the correct choices to enhance its efficiency in order to achieve its goals. The firm also intends to expand its workforce in the US, its biggest market. It announced a plan to employ 10,000 Americans in the United States [36]. Digital labour management, process re-engineering, talent and value chain sharing innovation-these are future outsourcing opportunities.

\section{REFERENCES :}

[1] Infosys Success: From Borrowed \$250 To Global IT Giant - Brand Riddle. Brand Riddle. Retrieved from https://brandriddle.com/infosys-from-borrowed-250-to-global-it-giant/ on 10/08/2019.

[2] Gopalakrishnan, S., Technologies, I., \&Moorthi, Y. L. R. (2011). Non-linear growth: The road ahead for Indian IT outsourcing companies The Infosys experience: In conversation with. IIMB Management Review, 23(2), 91-101. DOI: https://doi.org/10.1016/j.iimb.2011.04.009.

[3] Vision And Mission Of Infosys In Consulting And It Services Business Essay. UKEssays.com. Retrieved from https://www.ukessays.com/essays/business/vision-andmission-of-infosys-in-consulting-and-it-services-business-essay.php on 08/08/2019.

[4] Infosys Limited. Innovative IT Business Solutions \& Services for Industries | Infosys. Retrieved from https://www.infosys.com/services/ on 10/10/2019.

[5] Infosys Limited. Infosys BPM - Services | Business Processes Management. Retrieve from https://www.infosysbpm.com/offerings/functions/pages/index.aspx on 10/10/2019.

[6] Arora, Ashish, Arunachalam, V. S., Asundi, Jai ; Fernandes, Ronald (2001). The Indian software services industry. Research Policy, 30 (8),1267-1287. 
[7] Patel, D. (2017). The Pros and Cons of Outsourcing. Forbes. Retrieved from https://www.forbes.com/sites/deeppatel/2017/07/17/the-pros-and-cons-of-outsourcing-andthe-effect-on-company-culture/ on 08/08/2019.

[8] Humphreys, P. K. , A study of performance measurement in the outsourcing decision Research executive summaries series. Sciencedirect, 4(3). Retrieved- on 20/08/2019.

[9] Mcivor, R., Humphreys, P., Mckittrick, A., \& Wall, T. (2009). Performance management and the outsourcing process. International Journal of Operations \& Production Management, 29(10), 1025-1048.

[10] Soltanifar, M. (2016). Infosys: A Case Study on Becoming a Global Brand in Consulting Technology and Outsourcing Solutions. Multinational Management, 149-170.

[11] Heeks, R., (1996). India's Software Industry: State Policy, Liberalization and Industrial Development.Sage Publications, New Delhi, Thousand Oaks, London.

[12] Secretariat, U. (1992). Enhancing Competitiveness of Potential Export Sectors in Developing Countries--Lessons from Experience. Foreign Trade Review, 27(3), 305-317.

[13] Republic, S., \& Republic, S. (2010). Outsourcing: Decision making in the case of outsourcing the company activity and the management of outsourcing project. 2010(8), 387-396.

[14] Standard, B. Company - Business Standard. Www.business-standard.com. Retrieved from https://www.business-standard.com/company/infosys-2806/information/company-history on $\underline{08 / 09 / 2019}$.

[15] Sood, V. (2019). Infosys Drafts A New Strategy To Focus On Growth From Top Clients. Retrieved from https://www.livemint.com/companies/news/infosys-drafts-a-new-strategy-tofocus-on-growth-from-top-clients-1549218467933.html on 02/09/2019.

[16] Infosys Limited. Infosys - The 37th Annual General Meeting AGM 2018. Retrieved from https://www.infosys.com/investors/news-events/annual-general-meeting/2018/on 08/09/2019.

[17] Narayanamurthy, N. R.(2000). “Making India a significant IT player in this millennium”, in Romila Thapar (ed.), India: Another Millennium, New Delhi: Viking and Penguin Books.

[18] Schware, R. (1992). Software industry entry strategies for developing countries: A "walking on two legs” proposition. World Development, 20(2), 143-164.

[19] Infosys Limited. , Infosys Named A Leader Among API Strategy And Delivery Service Providers In 2019 Report. Retrieved from https://www.infosys.com/newsroom/pressreleases/Pages/leader-api-strategy-delivery-service-providers2019.aspx on 02/09/2019.

[20] APIs For Every Business. Retrieved from

https://www.infosysblogs.com/infosysdigital/2016/12/apis_for_every_business.html

on 02/09/2019.

[21] Home. Retrieved from https://finshiksha.com/finshiksha-quick-company-analysis-it-sector-inindia-infosys-ltd/ on 02/08/2019.

[22] chedgemakers. (2011). Infosys. Retrieved from https://www.slideshare.net/chedgemakers/infosys-7111657 on 02/08/2019.

[23] Infosys Limited. , Infosys - Innovation-Led Business Growth For Global Enterprises | Products \& Platforms. Retrieved from https://www.infosys.com/products-and-platforms/ on $10 / 9 / 2019$

[24] Infosys Limited., Infosys Global Subsidiaries Information | About Us. Retrieved from https://www.infosys.com/about/Pages/subsidiaries.aspx on 15/08/2019.

[25] Infosys Total Assets 2006-2019| INFY. Retrieved from 
https://www.macrotrends.net/stocks/charts/INFY/infosys/total-assets on 17/09/2019.

[26] Craytheon. Retrieved from

https://craytheon.com/financials/fundamental stock analysis cagr annual growth rate tren d chart.php ?company=INFY on 17/09/2019.

[27] Infosys Competitors, Revenue and Employees - Owler Company Profile. Retrieved from https://www.owler.com/company/infosys on 20/08/2019.

[28] Infosys - Wikipedia. Wikipedia. Retrieved from https://en.wikipedia.org/wiki/Infosys on 01/09/2019.

[29] Who are the clients of Infosys?. Quora. Retrieved from https://www.quora.com/Who-are-theclients-of-Infosys on 17/09/2019.

[30] Infosys Limited. , Infosys Sustainability: Corporate Responsibility Initiative. Retrieved from https://www.infosys.com/sustainability on 10/08/2019.

[31] Org Chart Infosys. The Official Board. Retrieved from https://www.theofficialboard.com/orgchart/infosys on 17/09/2019.

[32] Infosys Limited SWOT Analysis Matrix (Strengths, Weakness, Opportunities, Threats). Department, S. M.. Retrieved from http://fernfortuniversity.com/termpapers/swot/nyse/3622-infosys-limited.php on 14/09/2019.

[33] Zigu.,Infosys SWOT Analysis | Competitors \& USP | BrandGuide | MBA SkoolStudy.Learn.Share. MBA Skool-Study.Learn.Share. Retrieved from https://www.mbaskool.com/brandguide/it-technology/350-infosys.html on 14/09/2019.

[34] Mendonca, J., \&Pramanik, A. (2019). Infosys Sees Cloud \& Analytics As Future Billiondollar Units. The India Times. Retrieved from https://economictimes.indiatimes.com/industry/tech/infosys-sees-cloud-analytics-as-futurebillion-dollar-units/articleshow/68194524.cms?from=mdr on 21/08/2019.

[35] Gupta, S., \&Dzharova, H. (2014). ScienceDirect Innovation and adaptation: Continuing the Infosys journey In conversation with S . D .Shibulal, Co-founder ,. IIMB Management Review, 26(4), 249-256. DOI: https://doi.org/10.1016/j.iimb.2014.08.001

[36] Infotech. (2019). Infosys Achieves \$1.035 Billion Digital Revenues | InfotechLead. Retrieved from https://infotechlead.com/bpo/infosys-achieves-1-035-billion-digital-revenues-58235 on 17/09/2019. 